\title{
Determinants of Brand Loyalty in Health Sector of Pakistan
}

\author{
*Fozia Malik, Usman Asif, Omer Malik \\ Riphah International University Islamabad, Pakistan \\ *fmalik@consultant.com
}

\begin{abstract}
The purpose of this paper is to investigate the determinants of brand loyalty in health sector of Pakistan, the main theme is to study the relationship between dependent variable that is brand loyalty and determinants of brand loyalty i.e. independent variables that are brand knowledge, brand social responsibility image, service involvement and perceived service quality. Data was collected through questionnaire from customers of the health sector industry in twin cities of Islamabad and Rawalpindi. Out of 200 questionnaires 175 questionnaires received back in which 160 were properly filled which shows $80 \%$ response rate that is highly positive response. The results show that the independent variables have significant impact on dependent variable (brand loyalty). We have limited our research to the health sector of the twin cities i.e. Islamabad and Rawalpindi only, rather than the entire health industry of Pakistan. Research related to in depth analysis of the topic can be further done in different multiple dimensions. One can include much more complex demographics portion in the study in order to find out for example the impact of gender on the variable of brand loyalty.
\end{abstract}

Keywords: Brand knowledge, brand social responsibility image, service involvement perceived service quality, brand loyalty

\section{Introduction}

In the recent business scenario, the consumers have been exposed to number of brand choices for a single product category. The competition in the market place is becoming intense; previously isolated markets now have become the global markets. Therefore, the firm survival depends upon how superiorly it can create and move its brand in the market in order to create differentiation as the consumers observe greater differences in the brand than in the product-associated benefits (Rio et al, 2001). Focus of this research is to learn the effect of brand social responsibility image on brand loyalty relative to a health services offerings from the hospitals situated within the twin cities of Rawalpindi and Islamabad. For this research, the term product is used to infer a tangible aspect of the brand is offering. The importance of the perceived service quality cannot be ignored. The scope of this research is that it provides the insight of BSRI, Brand Knowledge, Perceived Service Quality and Service Involvement in determining the brand loyalty. For fast moving consumer goods (FMCG's) the importance of Brand Social Responsibility Image is even more, as per the importance the fact that they are most consumed and frequently consumed items so customers are very sensitive that either they fulfills legal responsibilities or not. "Consumer's opinion of a product's/service (or a brand's) ability to fulfill his or her expectations. It may have little or nothing to do with the actual excellence of the product, and is based on the firms (or brand's) current public image (corporate image), consumer's experience with the firm's other products, and the influence of the opinion leaders, consumer's peer group, and others. There are many researches, which pointed out the existence of a relationship between the variable Brand Loyalty and health care services. Due to the limitation of space, we have selected just three of those. Bloemer, Ruyter and Wetzels (1999) in their research concluded that, empathy along with word-of-mouth usually are the two most important determinants in order to predict purchase intention regarding health care services. These authors further added that perceived knowledge, skills, credentials and reputation are also most important factors to the consumers and to remain loyal under increasing service charges. The study strongly supports the service quality, loyalty relationship (Bloemer et al, 1999). Another study similar in results found that there is a positive relationship between perceived service quality, preference loyalty and price indifference loyalty. It further elaborated that those services in which low switching costs prevails, less loyalty from the customers will be shown and vice versa (Bloemer, Ruyter and Wetzels, 1998). In the third and the last study health care along with beauty category were tested whether the brand loyalty exists or not in these respected 
categories. The answer was again simple and similar in fashion. Brand loyalty does exist in health and beauty categories for both cognitive and emotional reasons (Rio et al, 2001). The researches show that it is important to identify the determinants of brand loyalty in health sector of Pakistan; the determinants, which are important for health sector of Pakistan, are brand knowledge, brand social responsibility image, service involvement and perceived service quality. The purpose of this research is to identifying the determinants of brand loyalty in health sector as this sector is neglected previously.

\section{Literature Review}

Brand Knowledge: Research shows that brand knowledge described as evoke of a brand when a customer is exposed to some external stimulus (Leong, Ang and Tham, 1996). It is important to know that what brand knowledge is composed of must be understood very carefully as it manipulate what comes to customers mind as a response to marketing activity for that particular brand (Keller, 1993). As we know that the Brand knowledge is one of the most important elements that boost marketing efficiency, the knowledge that has been knotted with the brand in a customer's mind significantly influences the consumer information process of a brand (Keller, 1993). Therefore, it is valuable to look at how the different level of brand knowledge affect and predict attendee behaviors. Brand knowledge is about the perception and the ideas consumers have in their mind and what memories they have about the brand, in all that brand association and brand awareness (Keller, 2003). Researchers shows that brand knowledge have shown different scope, making brand knowledge including awareness attribute features, benefits personal value, images visual information, thoughts personal cognitive, feelings personal affective, attitude judgment and experience purchase, further defined customer based brand equity in terms of brand knowledge conceptualizing brand knowledge in terms of brand awareness and brand image (Keller, 1993). Brand knowledge relates to the thought processes, the cognitive (intuitive) representation of the brand (Olson, 2002). Researcher has many different perceptual and cognitive elements that affect the customers and their knowledge, brand knowledge play very important part in this context (Aaker, 1996). Brand knowledge is central to the concept of customer based brand equity that is reflected in the form of positive or negative consumer response towards the brand. Additionally, the better a customer is known to a brand the greater the customer will exhibit brand equity behavior (Hutton, 1997). Brand knowledge plays a very important part in order to determine the customer's perception and attitude towards the brand. Especially for the retailers i.e. how they place their brand and what perception customers have about their particular brand (Chen and He, 2003). As we know that Brand Knowledge is getting importance and acceptance and more and more practitioners now stressing much on this terminology, it basically depends on or we may say that it constitutes strong brand awareness and brand associations that will eventfully help in making customers perceptions and preference that will help improving brand loyalty (Keller, 1993). One study shows that the importance of the Brand Knowledge i.e. what exactly customers know about a particular brand has a very demanding affect on the overall Brand Loyalty. Therefore, we may say that it is important to have a clear understanding of Brand Knowledge in order to know and predict the Brand Loyalty (Hsu and Liping, 2009). Brand Knowledge has to be in association with the Brand Loyalty; both have very influential affects on each other. Brand Knowledge is determined through brand association and brand awareness and all this leads toward strong brand loyalty. To determine the Brand Loyalty, Brand Knowledge has to be addressed properly and should cover all areas that determine it (Chaudhuri and Holbrook, 2001). The brand image is not only helpful for a company operations at local level but a positive image associated with a brand is even more helpful to multinationals and global firms in order to enhance their respective Brand Loyalties. In fact intense competition as an outcome of globalization has even increased the need for a consistent benefit based multi dimension applicable to both local and global levels (Hsieh, 2002).

Brand Social Responsibility Image: Brand Social Responsibility Image (BSRI) has a very strong relation and influencing effect on the ethics part (Litz, 1996) and morals (Logsdon \& Yuthas, 1997). The concept of Brand Social Responsibility Image is not very old; it is a recent phenomenon (Pava \& Krausz, 1996). The concept of the Brand Social Responsibility Image is not very simple and straightforward. Detailed researches have to be conducted in a particular society in order to know their customs in order to get better help in developing effective strategies (Marphy \& Enis, 1986). The concept of BSRI is very important in today's market, as we know that the customers are more knowledgeable and have more options to go for, we know that the power belong to them, as a result the marketers have to be very responsible in terms of social benefit. As we know 
that, the societies have a strong impact on the individuals so marketers have to take care of that (Wood, 1991). Literature clearly shows that the intent for doing more and more research on the socially responsiveness is gaining more importance as the marketers know that how important this factor is. Most of the companies fail not because of their product cheapness but not for socially responsible (Mark-Herbert and Schantz, 2007). Research shows that there are many strategies that a company can adopt in order to prove itself as a socially responsible and all the brands that come under its offerings are for the well being of the society (Meehan, Meehan and Richards, 2006). Research shows that in Thai retail banking sector social responsibility have big roles to play as customers have very deep affiliation with their society so they cannot favor any socially irresponsible brand (Poolthong and Mandhachitara, 2009). This paper changes the base of competition among the competitor finding suggest that now the battle is that which company is more socially responsible and doing work for the well-being of the society and for that it has to be very strong in its strategies and their true implementation (Galbreath, 2009). "Because the interest in social responsibility is growing (Parsa \& Khan, 1993), it should be of value to managers and owners of hospitality firms to have empirical information on the potential influence of a firm's level of social responsibility effort. Therefore, this research studied the importance of consumer social responsibility orientation and brand social responsibility image in the determination of brand loyalty". Research on Brand Social Responsibility Image is being the center of attention for most of the researchers for the last decade or so, especially for the sensitive and more frequently used (high demand) products like mobiles phones and it directly influence the loyalty and evidence is there that a socially responsible brand have more acceptance and greater brand loyalty (Salmones, Crespo and Bosque, 2005). In today intense competition, it is very important to know your customers and their perceptions about the brand and for that a company have to be socially responsible and that will eventually raised the brand loyalty (Bloom, Hoeffler, Keller and Basurto Meza, 2006). Another paper investigated the relationship of Brand Social Responsibility Image and Loyalty and the other factors that have influence on these variables like customers perception, awareness and association with the brand (Hsieh and Li, 2008).

Perceived Service Quality: One study concerning the automobiles sector highlighted that the consumers form the perception regarding quality (perceived quality) on a very limited set of information. In the modern days consumer has perceived quality is more realistic and closely aligned with the real quality of a product or a service. A study comprising of 162 brands in total found out that the advertising expenditure is positively correlated to the perceived service quality (Moorthy and Zhao, 2000). A study concerning mobile phones perceived service quality and its relationship with brand loyalty found that the perceived service quality has a significant and predictive influence on brand loyalty (Sirgy et al., 2009). One study concluded by saying that the perceived service quality can increase or decrease the service ratings offered by a company, so the perceived service quality should be considered as important one (Saliba et al., 2005). Ha and John (2009) gathered data from the retail banks and discount store retailing services for their study in which they concluded there study by pointing out a direct and strong relationship between the brand loyalty and the perceived service quality. In another attempt a researcher-defined loyalty as self-reported, repurchase behavior instead of purchase intention. Further findings of this same paper emphasized that there exists a strong relationship between brand loyalty and perceived service quality when comparative evaluations are being performed as compared to just single one (Olsen, 2002). Two researchers namely Yang and Wang (2010), also concluded that the two variables i.e. brand loyalty and perceived service quality both are strongly correlated. This respective research considered low and medium priced store brands while conducting the research.

Product/Service Involvement: Motivation is aroused in a consumer when he/she search is for information by his/her involvement in an object (Bloch et al., 1986). Involvement can be defined as; "One's perception of the degree of personal relevance towards an object" (Krugman, 1967). Product/Service involvement tends to lead an individual toward information search, as certain products or brands are related to an individual's ego or self-image (Bloch and Richins, 1983). According to the business dictionary high involvement is defined as; "High capital value good that is purchased only after long and careful consideration, such as a car, truck, crane". The involvement component may help us in proper understanding of service consumption behavior and will be likely to affect that how different service dimensions can be constructed (Gabbott and Hogg, 1999). The relationship between the brand loyalty and product/service involvement depends upon the different aspects of product/service involvement and is thus specific for each product concerned. These two 
variables are not universal constructs rather they differ from product to product bases (Quester and Lim, 2003). These two also concluded that product/service involvement does not predict brand loyalty. Other researchers as if (Iwasaki and Havitz, 1998) also mentioned that product/service involvement cannot and does not precede brand loyalty. They further argued that people indulge in psychological processes in order to be loyal. According to these researchers, the highly loyal individuals tend to show high involvement levels. (LeClerc and Little, 1997) only indicated that the repeated purchases in case of high involvement services/products depict brand loyalty. They further elaborated that the repeated purchases in case of low involvement services/products are just habitual. Another study concerning Swiss hotels concluded with a result that product/service involvement has a strong relationship on brand loyalty (Hochgraefe, Faulk and Vieregge, 2009). As compared to overall satisfaction, the brand trust (brand loyalty) supported by high service involvement are significant variables that generates a high level of customer commitment (Ballester and Aleman, 2001). Another study reports that the phenomena of consumers involvement in a service can be identical across national borders and a standardized marketing campaign across can be valid in this regard (Dahringer et al., 1991).

Brand Loyalty: The brand loyalty is the trust that customer has on a brand. The increasing importance of brand loyalty in context of BCRI is due to the fact it yields different benefits including increased sales, repeat purchase etc. (Ballester and Aleman, 2001). A blessing to strong brand is that they enjoy brand loyalty an ability to charge price premium and brand power to support new product launch (Ghodeswar, 2008). It is an asset that cannot be easily copied by the competitors also the importance of building and maintaining brand loyalty in case of restaurant industry is high due to number of risks associated with service and the relationship between risk aversion and loyalty is evident (Matzler, Krauter \& Bidman, 2008). The higher the risk involved in a purchase the higher the loyalty plays the role, for instance home appliances are expensive and have some risk involved so the customer will purchase most probably the previously owned brand from which the customer had positive Experience and satisfaction (Bayus, 1992). But maintaining loyalty among the customers is not that much easy task as there are many forces driving the customers to be disloyal including competitors and brand choices available (Ha, 1998). The length of a time customer is using a particular brand and the customer's usage experience is the factors that determine brand loyalty (Erdem and Swait, 1998). The concept of brand loyalty is equally important in industrial goods, services and retail business as it decrease the probability of customer switching and involves the customer in repeat purchase behavior (Thiele and Bennett, 2001). The profit and market shares are closely associated with the brand equity, as more purchase loyalty will lead to increase in market shares and attitudinal loyalty will lead to higher relative price for the Brand (Chaudhuri and Holbrook, 2001). Through loyalty the customers develops likeness towards the brand (McConnell, 1968).

Figure 1: Theoretical Framework

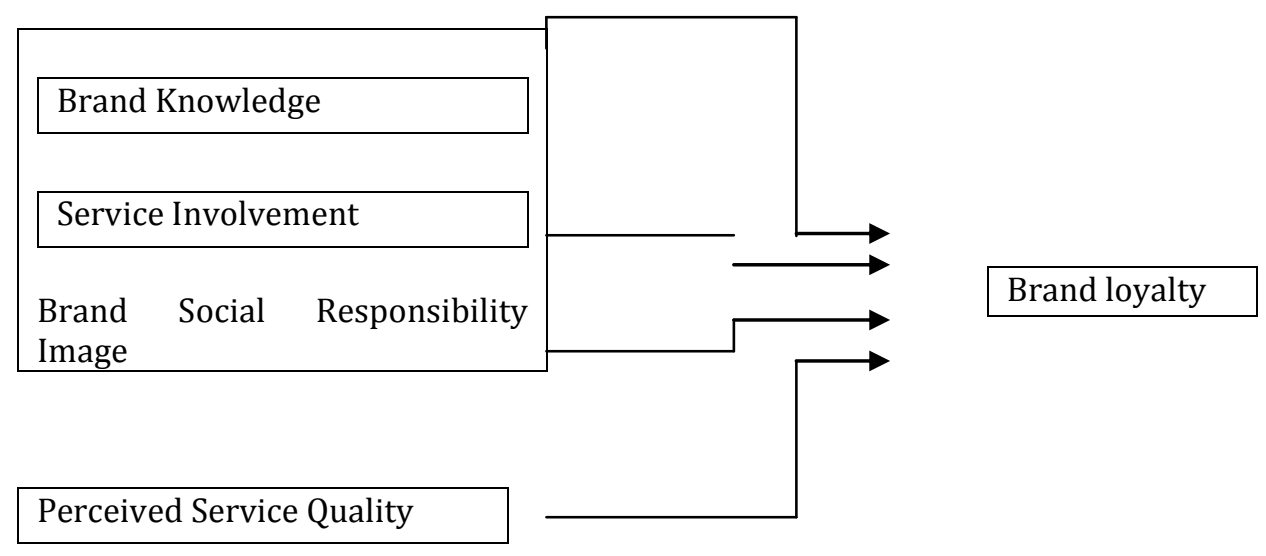

\section{Hypothesis}

$\mathbf{H}_{1}$ : There is a positive relationship between brand social responsibility image and brand loyalty. $\mathbf{H}_{2}$ : There is a positive relationship between perceived service quality and brand loyalty. 
$\mathbf{H}_{3}$ : There is a positive relationship between service involvement and brand loyalty.

$\mathbf{H}_{4}$ : There is a positive relationship between brand knowledge and brand loyalty.

\section{Methodology}

The main purpose of this research was to identify the determinants of brand loyalty in health sector of Pakistan, the survey was conducted using convenience-sampling technique, 200 questionnaires were distributed in Rawalpindi and Islamabad, and 172 questionnaires were received back out of which 12 questionnaires were not completely filled, so the sample size for this research is 160 . The instrument was adopted from various sources e.g. brand loyalty, service involvement, brand knowledge, brand social responsibility image and perceived service quality are adopted from Quester and Lim, (2003), Wulf et al., (2001), Young \& Rubicam, (1994) and Reich, (2002) respectively.

\section{Results \& Discussion}

Table 1: Correlation Analysis

\begin{tabular}{|c|c|c|c|c|c|}
\hline & $\begin{array}{c}\text { Brand } \\
\text { Loyalty }\end{array}$ & $\begin{array}{c}\text { Service } \\
\text { Involvement }\end{array}$ & $\begin{array}{c}\text { Brand } \\
\text { Knowledge }\end{array}$ & $\begin{array}{c}\text { Perceived Service } \\
\text { Quality }\end{array}$ & $\begin{array}{c}\text { Brand Social } \\
\text { Responsibility Image }\end{array}$ \\
\hline Brand Loyalty & .78 & & & & \\
\hline $\begin{array}{l}\text { Service } \\
\text { Involvement }\end{array}$ & $.632^{* *}$ & .82 & & & \\
\hline Brand Knowledge & $.667^{* *}$ & $.319^{* *}$ & .79 & & \\
\hline $\begin{array}{l}\text { Perceived Service } \\
\text { Quality }\end{array}$ & $.747^{* *}$ & $.647^{* *}$ & $.358^{* *}$ & .88 & \\
\hline $\begin{array}{l}\text { Brand Social } \\
\text { Responsibility } \\
\text { Image }\end{array}$ & $.588^{* *}$ & $.302^{* *}$ & $.469^{* *}$ & $.457^{* *}$ & .85 \\
\hline
\end{tabular}

** Correlation is significant at $0.01, \mathrm{n}=160$, Cronbach Alpha Values are in Italic

The above table clearly shows the correlation between the five variables of the study namely Brand Loyalty, Service Involvement, Brand Knowledge, Perceived Service Quality and the last one Brand Social Responsibility Image. As mentioned earlier in the thesis, the dependent variable is Brand Loyalty and the rest of four are independent variables namely; Service Involvement, Brand Knowledge, Perceived Service Quality and Brand Social Responsibility Image. Brand Loyalty has a positive correlation with the rest of variables. Brand Loyalty correlation of $0.632,0.667,0.747$, and 0.588 is recorded with Service Involvement, Brand Knowledge, Perceived Service Quality and Brand Social Responsibility Image respectively. As one can see, all of the relations are positive in nature but each relationship is of different strength and nature. The correlation between Brand Loyalty and Perceived Service Quality is of maximum strength i.e. 0.747. It is because of the fact that we have chosen the health service sector of Pakistan. A person who is using or is associated with the health services seems to be more quality conscious as compared to others. As a bad treatment can lead or can be associated with the pain and even death of an individual, quality remains at the top of the priority list for both patients and the relatives. The correlation between Brand Loyalty and the Brand Social Responsibility Image is though positive but is of the most weakest nature i.e. 0.588. A simple argument to explain this phenomenon can be that Pakistanis somehow generally feel that it does not matter whether the brand is socially responsible or not when it comes to health related services. Each service sector of Pakistan is of different nature and individuals perceive them separately. So a strong correlation of Brand Loyalty with Brand Social Responsibility Image in suppose FMCG sector can prevail but in case of Health services sector it can be all together different as shown by our study. A correlation of 0.667 can be witnessed between the Brand Loyalty and the Brand Knowledge, which is quite strong. Branding is no doubt is the most religiously followed fashion of the marketing world. Having its own long lasting advantages, the same is the case for the health services sector of Pakistan. One point, which our group wants to mention here, is that mostly Shifa 
International Hospital was pointed out as the most preferred hospital or the brand related to the health services sector of the twin cities. Service Involvement is the variable, which has a 0.632 correlation with Brand Loyalty, again a positive one. As mentioned earlier, that the chosen service sector was health services so it makes sense. Health services is not an ordinary service, it is something that most of us are badly involved in consuming it on regular bases. Different types of infections and diseases are on the rise because of the repeated use of infected medical instruments. Therefore, it makes sense that an individual should be involved while having a medical treatment. The same is the result reflected by the respective correlation

Table 2: Regression Analysis, Model Summary

Model Sum mary

\begin{tabular}{|c|c|c|c|c|}
\hline Model & $\mathbf{R}$ & R Square & Adjusted R Square & $\begin{array}{l}\text { Std. Error of } \\
\text { the Estim a te }\end{array}$ \\
\hline 1 & $.883^{\mathrm{a}}$ & .780 & .775 & .24737 \\
\hline
\end{tabular}

a. Predictors: (Con stant), Respons ibility Mean, In volvementMean, Kn owled geMean, Qu ality Mean

The values of $\mathrm{R}$ for models produced by the regression procedure range from 0 to 1 . $\mathrm{R}$ square is the proportion of variation in the dependent variable explained by the regression model and the values of $R$ square range from 0 to 1 . Small values indicate that the model does not fit the data well. In simple terms, the $\mathrm{R}$ square tends to optimistically estimate how well the model fits the population. Adjusted R squared attempts to correct $\mathrm{R}$ square to more close reflection of the goodness of model fit in the population. $\mathrm{R}$ Square helps in determining which model is best. As depicted by the regression table the R square is 0.780 , which shows a good fit between the model and the population. Simply it shows that the impact of independent variables i.e. Service Involvement, Brand Knowledge, Perceived Service Quality and Brand Social Responsibility Image on the dependent variable i.e. Brand strength is $78 \%$, which is quite strong. Overall, the model reflects that it is significant.

Table 3: Regression Analysis, ANOVA

\begin{tabular}{llrrrrr}
\multicolumn{7}{c}{ ANOVA $^{\mathbf{b}}$} \\
\hline \hline Model & & Sum of Squares & df & Mean Square & F & Sig. \\
\hline 1 & Regression & 33.681 & 4 & 8.420 & 137.606 & $.000^{\mathbf{a}}$ \\
& Residual & 9.485 & 155 & .061 & & \\
& Total & 43.165 & 159 & & & \\
& & & & & & \\
&
\end{tabular}

\footnotetext{
a. Predictors: (Constant), Responsibility Mean, InvolvementMean, Kno wledg eMean, QualityMean
}

b. Dependent Variable: Loy altyMean

In the ANOVA table, the value of $\mathrm{F}=137.606$ which is significant at .000 level. $\mathrm{F}$ value should be greater than 5 and should not be less than 2 . Here, it is $\mathbf{1 3 7 . 6 0 6}$ which is a significant at .000 level and shows over all model significance as well. 
Table 4: Regression Analysis, Coefficients

Coefficients ${ }^{\mathrm{a}}$

\begin{tabular}{|c|c|c|c|c|c|c|}
\hline \multirow[b]{2}{*}{ Model } & & \multicolumn{2}{|c|}{ Unstandardized Coefficients } & \multirow{2}{*}{$\begin{array}{c}\begin{array}{c}\text { Standardized } \\
\text { Coefficients }\end{array} \\
\text { Beta }\end{array}$} & \multirow[b]{2}{*}{$\mathrm{t}$} & \multirow[b]{2}{*}{ Sig. } \\
\hline & & $\mathrm{B}$ & Std. Error & & & \\
\hline \multirow[t]{5}{*}{1} & (Constant) & .637 & .158 & & 4.032 & .000 \\
\hline & InvolvementMean & .170 & .043 & .197 & 3.955 & .000 \\
\hline & Know ledge Me an & .298 & .034 & .382 & 8.731 & .000 \\
\hline & Quality Mean & .338 & .044 & .409 & 7.705 & .000 \\
\hline & Responsibility Mean & .104 & .029 & .162 & 3.565 & .000 \\
\hline
\end{tabular}

a. Dependent Variable: Loy alty Mean

Coefficients table shows the inconsistency which is caused by the independent variable on the dependent variable. The Beta statistics shows that how much independent variable change has affected the dependent variable. The values of $t$ can be seen that the value is greater than 10. The values for $t$ of the independent variables are more than 2 except in the case of Brand Social Responsibility Image. The value of $t$ should be greater than 2. It can be easily analyzed that the value of $t$ of an independent variables is significant at level $\mathrm{p}<0.01$. The regression value of the independent value is positive as well as quite significant. Therefore, it is also evident from here that the results of regression compliment the significant impact of independent variable on brand loyalty. Table reflects the values of Beta, which shows that how much independent variable change has affected the dependent variable. As the value of $t$ should be greater than 2 , we can see that all variables have value of $\mathrm{t}$ greater than 3 .

Discussion: As by observing the findings we can clearly understand that brand loyalty is highly dependent on respective independent variables. Therefore, an improvement in the independent variables have resulted an increase in the brand loyalty of health sector. As a consequence, all of the four independent variables namely Brand Social Responsibility Image, Brand Knowledge, Perceived Service Quality and Service Involvement have a strong impact on the Brand Loyalty. We can say that now people go after the good brand names, which are present in the health services sector of Pakistan. Therefore, it is important for the health services sector to build strong brands for over all excellent brand loyalty. Correlation indicates that independent variables when increased have a strong positive impact on the brand loyalty in the health services sector (hospitals). In the regression analysis, we have studied the impact of independent variables on brand loyalty. And thus we have concluded that the independent variable has a positive and significant impact on our dependent variable as the value of the $\mathrm{R}$ square is .780, showing the overall model is perfect and have strong relation between the dependent and independent variable. This study is basically conducted to measure the relationship between brand knowledge, service involvement, and perceived service quality and brand social responsibility image on brand loyalty for health sector of Pakistan. We have to measure the brand loyalty of hospitals considering independent variables as the way to measure loyalty. Brands are powerful assets that must be carefully developed and managed.

\section{Recommendations}

Based on our analysis with the help of correlation and regression we propose the following recommendations for the health services sector of Pakistan and especially for their respective management. As shown by the results, Perceived Service Quality is the most important variable in determining the Brand Loyalty so hospitals should strive for quality in order to make their consumers more Brand loyal. Special infomercials can be used in order to increase the Perceived Service Quality of a particular hospital brand. Hospitals should also provide the target market with enough knowledge regarding the services they render under their brand in order to increase their Brand Loyalty. Getting the consumers involved while delivering services should also be one of the aims for the management as this will lead towards high brand loyalty. However, Brand Social 
Responsibility Image according to this research is not as strongly related to Brand Loyalty as compared to Perceived Service Quality and other variables involved but we cannot completely ignore it. Efforts should be made in this direction as well in order to spread awareness about a particular hospital brand which is not only taking money from the society but is actually giving back so much in return. Obviously, this will increase the good will of the brand and ultimately the Sales. Marketing cannot be ignored because it has a vital part to play when Brand Loyalty is talked about. It is only delivering an aim-oriented message across via television, radio or newspapers; rather it is the persistent and consistent actions and practices, which the hospital administration, staff, doctors and nurses are used to. Integrated Marketing Communications (IMC) should be the way forward.

Limitations: We have limited our research to the health sector of the twin cities i.e. Islamabad and Rawalpindi only, rather than the entire health industry of Pakistan. We have selected 4 independent variables that are brand social responsibility image, service involvement, brand knowledge and perceived service quality to study how they affects the brand loyalty. There are many other factors and variables, which may affect the brand loyalty, which we have not considered for our research due to time constraints and limited resources. Through these four independent variables, we tried to measure the brand loyalty. Moreover, the study encompasses the local people (students, teachers, and job - oriented people) selected from the twin cities of Pakistan i.e., Rawalpindi and Islamabad and thus we do not look at the entire consumer population. Finally, we have concentrated on general demographics like age, gender, education, occupation, income level, marital status etc. As a consequence, a lot of insight is still waiting to be explored.

Future Implications: Research related to in depth analysis of the topic can be further done in different multiple dimensions. One can include much more complex demographics portion in the study in order to find out for example the impact of gender on the variable of brand loyalty. Similarly, another can be carried out for the purpose of finding and investigating the other variables involved in predicting the brand loyalty. Same model adopted for this research can and should be checked against the retail as well as the FMCG's market and results could then be analyzed and compared with each sector. Income level can also be studied in relation to the brand loyalty variable. Therefore, to conclude with, we can say that each research provides and proves to open many multiple dimensions and paths on which a researcher can walk through and explore the world of numerous possibilities.

\section{References}

Aaker, D. A. (1996). Measuring Brand Equity across Products and Markets. California Management Review, 38(3), 102-118.

Ballester, E. D. \& Aleman, J. L. M. (2001). Brand trust in the context of consumer loyalty. European Journal of Marketing, 35(11/12), 1238-1258.

Bloch, P. H., Sherrell, D. L. \& Ridgway, N. M. (1986). Consumer search: an extended framework. Journal of Consumer Research, 13, 119-26.

Bloch, P. H. \& Richins, M. L. (1983). A theoretical model for the study of product importance perceptions. Journal of Marketing, 47, 69-81.

Bloemer, J., Rayter, K. D. \& Wetzel, M. (1999). Linking perceived service quality and service loyalty: a multidimensional perspective. Journal of Marketing, 33(11/12).

Bloemer, J., Rayter, K. D. \& Wetzel, M. (1998). On the relationship between perceived service qualities, service loyalty and switching costs. International Journal of Service Industry Management, 9(5), 436-453.

Bayus, B. L. (1992). Brand Loyalty and marketing Strategy: An Application to Home Appliances. Marketing Science, 11(1), 21-38.

Bloom, P. N., Hoeffler, S., Keller, K. L. \& Basurto-Meza, C. E. (2006). How social-cause marketing affects consumer perceptions. MIT Sloan Management Review, 47(2), 49-55.

Chaudhuri, A. \& Holbrook, M. B. (2001). The Chain of Effects from Brand Trust and Brand Affect to Brand Performance: The Role of Brand Loyalty. American Marketing Association, 65(2), 81-93.

Chaudhuri, A. \& Holbrook, M. B. (2003). The chain of effects from brand trust and brand affect to brand performance the role of brand loyalty. Journal of Marketing, 65, 81-93.

Chen, R. \& He, F. (2003). Using brand knowledge to understand consumer's intention to adopt an online retailer. International Journal of Services Technology and Management, 4(3/6), 464-479. 
Dahringer, L. D., Frame, C. D., Yau, O. \& Kennedy, J. M. (1991). Consumer Involvement in Services. An International Evaluation. Journal of International Consumer Marketing, 3(2), 61 - 78.

Erdem, T. \& Swait, J. (1998). Brand Equity as a Signaling Phenomenon. Journal of Consumer Psychology, 7(2), 131-57.

Gabbot, M. \& Hogg, G. (1999). Consumer Involvement in Services: A Replication and Extension. Journal of Business Research, 46(2), 159-166.

Ghodeswar, B. M. (2008). Building Brand identity in competitive markets: a conceptual model. Journal of Product \& Brand Management, 17(1), 4-12.

Galbreath, J. (2009). Building corporate social responsibility into strategy. European Business Review, 21(2), $109-127$.

Hsu, C. \& Liping, A. C. (2009). Brand knowledge, Trust and Loyalty - A Conceptual Model of Destination Branding, Hospital \& Tourism Management, and International CHRIE Conference.

Ha, C. L. (1998). The theory of reasoned action applied to brand loyalty. Journal of product \& Brand Management, 7(1), 51-61.

Ha, H. Y. \& John, J. (2009). Role of customer orientation in an integrative model of brand loyalty in services. The Service Industries Journal, 6(3), 23-33.

Hutton, J. G. (1997). A study of Brand equity in an organizational-buying context. Journal of Product \& Brand management, 6(6), 428-439.

Hochgraefe, C., Faulk, S. \& Vieregge, M. (2009). Impact of Swiss Consumers' Product Involvement on Brand Loyalty, Hospitality \& Tourism Management. International Journal University of Massachusetts, 10(2), 14-19.

Hsieh, M. H. (2002). Identifying Brand Image Dimensionality and Measuring the Degree of Brand Globalization: A Cross-National Study. Journal of International Marketing, 10(2), 46-67.

Hsieh, A. T. \& Kai-Li, C. (2008). The moderating effect of brand Image on public relations perception and customer loyalty. Marketing Intelligence and Planning, 26(1), 26-42.

Iwasaki, Y. \& Havitz, M. E. (1998). A path-analytic model of the relationships between involvement, psychological commitment, and loyalty. Journal of Leisure Research, 30(2), 256-280.

Keller, K. L. (1993). Conceptualizing, measuring, and managing customer-based brand equity. Journal of Marketing, 57(1), 1-22.

Keller, K. L. (2003). Strategic brand management: Building, measuring and managing brand equity (second Ed). Upper Saddle River, NJ: Prentice Hall.

Krugman, H. E. (1967). The measurement of advertising involvement. Public Opinion Quarterly, 30, 583-96.

Leong, S. M., Ang, S. H. \& Tham, L. L. (1996). Increasing Brand Name Recall in Print Advertising among Asian Consumers. Journal of Advertising, 25(2), 65-81.

LeClerc, F. \& Little, J. D. C. (1997). Can advertising copy make FSI coupons more effective? Journal of Marketing Research, 34, 473-84.

Litz, R. A. (1996). A Resourced-Based-View of the Socially Responsible Firm: Stakeholder Interdependence, Ethical Awareness, and Issue Responsiveness as Strategic Assets. Journal of Business Ethics, 15, 13551363.

Logsdon, J. M. \& Yuthas, K. (1997). Corporate Social Performance, Stakeholder Orientation, and Organizational Moral Development. Journal of Business Ethics, 16, 1213-1226.

Matzler, K., Krauter, S. G. \& Bidmon, S. (2008). Risk aversion and brand loyalty: the mediating role of brand trust and brand affect. Journal of Product \& Brand Management, 17(3), 154-162.

McConnell, J. D. (1968). The Development of Brand Loyalty: An Experimental Study. Journal of Marketing Research, 5(1), 13-19.

Moorthy, S. \& Zhao, H. (2000). Advertising Spending and Perceived Quality. Marketing Letters, 221-233.

Mark-Herbert, C. \& Schantz, C. (2007). Communicating Corporate Social Responsibility - Brand management. Electronic Journal of Business Ethics and Organization Studies, 12(2), 4-11.

Meehan, J., Meehan, K. \& Richards, A. (2006). Corporate social responsibility: the 3C-SR model. International Journal of Social Economics, 33(5/6), $386-398$.

Murphay, P. E. \& Enis, B. M. (1986). Classifying products strategically. Journal of Marketing, 50, 24-42.

Olsen, S. 0. (2002). Comparative Evaluation and the Relationship between Quality, Satisfaction, and Repurchase Loyalty. Journal of the Academy of Marketing Science, 30(3), 240-249. 
Pava, M. L. \& Krausz, J. (1996). The Association between Corporate Social Responsibility and Financial Performance: The Paradox of Social Cost. Journal of Business Ethics, 15, 321-57.

Poolthong, Y. \& Mandhachitara, R. (2009). Customer expectations of CSR, perceived service quality and brand effect in Thai retail banking. International Journal of Bank Marketing, 27(6), 408 - 427.

Parsa, H. G. \& Khan, M. A. (1993). Quick-service restaurant of the 21st century: An analytical review of macro factors. Hospitality Research Journal, 17(1), 161-173.

Quester, P. \& Lim, A. L. (2003). Product involvement/brand loyalty: is there a link? Journal of Product \& Brand Management, 12(1), 22-38.

Reich, Z. A. (2002). The Influence of Consumer and Brand Social Responsibility on Brand Loyalty in QuickService Restaurants, Blacksburg Virginia. (Thesis)

Rio, D. B., Vazquez, R. \& Iglesias, V. (2001). The Role of the brand name in obtaining differential advantages. Journal of product and brand Management, 10(7), 452-465.

Saliba, A. J., Beresford, M. A., Ivanovich, M. \& Fitzpatrick, P. (2005). User perceived quality of service in wireless data networks. Springer-Verlag London Limited, 5(8).

Sirgy, M., Joseph, L., Dong, J. \& Tidwell, J. (2009). What Determines Perceived Quality-of-life Impact of Mobile Phones? A Model Based on the Consumption Life Cycle. Springer Science, Published, 8(2), 130.

Salmones, M. M. G., Crespo A. H. \& Bosque I. R. (2005). Influence of Corporate Social Responsibility on Loyalty and Valuation of Services. Journal of Business Ethics, 61(4), 369-385.

Thiele, S. R. \& Bennett, R. (2001). A brand for all seasons? A discussion of brand loyalty approaches and their applicability for different markets. Journal of Product \& Brand management, 12(1), 25-37.

Wulf, D. K., Schroeder, O. G. \& Iacobucci, D. (2001). Investments in consumer relationships: A cross country and cross-industry exploration. Journal of Marketing, 65(4), 33-50.

Wood, D. (1991). Corporate Social Performance Revisited. Academy of Management Review, 16, 691-718.

Young, A. \& Rubicam, E. (1994). Brand Asset Valuator, London: Young \& Rubicam.

Yang, H. \& Wang, X. (2010). The Effects of 2-tier Store Brands' Perceived Quality, Perceived Value, Brand Knowledge, and Attitude on Store Loyalty. Higher Education Press and Springer-Verlag, 4(1), 1-28. 